\title{
Development of educational material for the prevention and treatment of friction injuries
}

\section{Desenvolvimento de um material educativo para a prevenção e o tratamento das lesões por fricção}

\section{Desarrollo de material educativo para la prevención y tratamiento de lesiones por fricción}

\section{Geraldo Magela Salomé1,*}

ORCID IDS

Salomé GM (D) https://orcid.org/0000-0002-7315-4866

\section{HOW TO CITE}

Salomé GM. Development of educational material for the prevention and treatment of friction injuries. ESTIMA, Braz. J. Enterostomal Ther., 2020, 18: e3220. https://doi.org/10.30886/estima.v18.923_IN

\begin{abstract}
Objective: to develop and validate an educational booklet to help health professionals to prevent and treat friction injuries. Method: methodological study. An integrative review of the literature of journals published between 2009 and 2019 was carried out in the main databases of Health Sciences. The evaluation of the educational booklet was conducted with 32 nurses, using the Delphi technique. The statistical analysis used was the Content Validity Index. Results: the judges considered the content of the educational booklet between the concepts "inadequate" and "adequate", in the first assessment; after the corrections requested by the judges, the booklet was forwarded to the evaluators and the content of the educational booklet was rated between "adequate" and "totally adequate". The overall Content Validity Index was 0.8118 in the first assessment and 1.0 in the second assessment. Conclusion: after the integrative literature review, the material was constructed and validated by professionals with experience in evaluating and treating individuals with wounds, obtaining consensus among the evaluators in the second evaluation.
\end{abstract}

DESCRIPTORS: Friction; Wounds and injuries; Nursing assessment; Health education; Stomatherapy.

\footnotetext{
1. Universidade do Vale do Sapucaí - Programa de Mestrado Profissional em Ciências Aplicadas à Saúde - Pouso Alegre (MG), Brazil.
}

*Correspondence author: salomereiki@univas.edu.br

Received: Jul. 23, 2020 | Accepted: Nov. 20, 2020 


\section{RESUMO}

Objetivo: desenvolver e validar uma cartilha educativa para ajudar o profissional da saúde a prevenir e tratar da lesão por fricção. Método: estudo metodológico. Foi realizada revisão integrativa da literatura dos periódicos publicados entre 2009 e 2019 nas principais bases de dados de Ciências da Saúde. A avaliação da cartilha educativa foi conduzida com 32 enfermeiros, utilizando a técnica de Delphi. A análise estatística utilizada foi o Índice de Validade de Conteúdo. Resultados: os juízes consideraram o conteúdo da cartilha educativa entre os conceitos "inadequado" e "adequado", na primeira avaliação; após as correções solicitadas pelos juízes, a cartilha foi reenviada aos avaliadores e o conteúdo da cartilha educativa foi avaliado entre "adequado" e "totalmente adequado". O Índice de Validade de Conteúdo geral foi de 0,8118 na primeira avaliação e 1,0 na segunda avaliação. Conclusão: após a revisão integrativa da literatura, o material foi construído e validado por profissionais com experiência em avaliar e tratar de indivíduos com feridas, obtendo consenso entre os avaliadores na segunda avaliação.

DESCRITORES: Friç̧ão; Ferimentos e lesões; Avaliação em enfermagem; Educação em saúde; Estomaterapia.

\section{RESUMEN}

Objetivo: Desarrollar y validar una cartilla educativa para ayudar al profesional de la salud a prevenir y tratar lesiones por fricción. Método: estudio metodológico. Fue realizada revisión integradora de la literatura de los periódicos publicados entre 2009 y 2019 en las principales bases de datos de Ciencias de la Salud. La evaluación de la cartilla educativa fue realizada con 32 enfermeros, utilizando la técnica de Delphi. El análisis estadístico utilizada fue el Índice de Validez de Contenido. Resultados: los jueces consideraron el contenido de la cartilla educativa entre los conceptos «inadecuado» y «adecuado», en la primera evaluación; luego de las correcciones solicitadas por los jueces, la cartilla fue reenviada a los evaluadores y el contenido de la cartilla educativa fue evaluado entre «adecuado» y «totalmente adecuado». El Índice de Validez de Contenido general fue de 0,8118 en la primera evaluación y 1,0 en la segunda evaluación. Conclusión: luego de la revisión integradora de la literatura, el material fue construido y validado por profesionales con experiencia en evaluar y tratar individuos con heridas, obteniendo consenso entre los evaluadores en su segunda evaluación.

DESCRIPTORES: Fricción; Heridas y lesiones; Evaluación en enfermería; Educación en salud; Estomaterapia.

\section{INTRODUCTION}

The integument is the largest organ in the body, necessary for the survival of the human being and for the perfect physiological balance of the organism, being able to suffer aggressions by intrinsic and extrinsic pathological factors. These aggressions can cause changes in their constitution, such as burns, traumatic ulcers, dermatitis, friction injury (FI) and others, which can lead to the individual's functional disability and cause changes in their quality of life $\mathrm{e}^{1-3}$.

The professional who provides assistance to individuals who have risk factors or who have contracted FI has an important role in holistic care as well as performing extremely important work in the prevention and treatment of $\mathrm{FI}^{4,5}$.

FI comes from bruising, either by friction, trauma or shearing of the skin. The tension present in the retraction, friction or shock between the person's skin and the surface of the bed or surrounding materials can cause injuries of partial or full thickness ${ }^{6-9}$.

The body topography most affected by the FI is the back of the hands, the arms, the elbows and the legs of elderly or very young people as neonates. The production of serous exudate, especially in the first 24 hours, makes the FI mostly moist ${ }^{1-4}$.

Several studies report that $42 \%$ of FI are located on the elbows, $22 \%$ on the legs and $13 \%$ on the hands1-8.

For this reason, the nurse must assess the patient's skin at the time of admission and, from then on, daily; it should also guide health professionals and caregivers who assist these individuals in order to keep the skin dry and clean through maintenance, avoiding the occurrence of shear and, consequently, the $\mathrm{FI}^{9,10}$.

These guidelines can be given orally or in writing. It is also important to develop educational materials such as algorithms, booklets, protocols, applications, online courses, among others about preventive measures and therapeutic approaches ${ }^{11}$.

The construction of protocols, manuals, booklets, algorithms, guides and guidelines that include the best scientific evidence can favor the provision of assistance based on good clinical practices, promoting health improvement/recovery before the individual has been affected $^{11-13}$.

The validation of a booklet is an important process, as it determines whether the instrument is adequate to provide analytical measures and appropriate information 
for a given objective and context, such as the assessment of the presence of risk factors for FI, guidelines for prevention, treatment of this condition, among other factors. The validated booklets enable individualized and systematic care and the optimization of decision-making, which have the consequence of reducing costs with the care provided by health services and providing assistance with the minimum possible risk, without damage, in short, a care with quality and safety.

This study aimed to develop and validate the contents of a booklet for the prevention and treatment of FI. This booklet aims to provide subsidies to health professionals who provide assistance to individuals with FI or at risk, for the preparation and development of injury care plans, with appropriate prevention and treatment strategies, combining therapeutic conduct with a variety of propitious methods to execute it.

\section{OBJECTIVE}

To develop and validate an educational booklet to help health professionals to prevent and treat FI.

\section{METHOD}

This is a methodological study of production and validation of educational technology.

The process of constructing the educational booklet had the first version drawn up between March and August 2019. After the booklet was evaluated by the judges, several changes were made by the authors, and the final version was completed between November 2019 and March 2020. The content was aligned with the premises for the construction of educational materials for guidance on health care. The preparation of the material went through the following phases: situational diagnosis, integrative literature review, formulation and assembly of the educational booklet and its validation and implementation ${ }^{11,12}$.

\section{First stage: situational diagnosis}

The idea of writing the booklet was born from observations made during the researchers' clinical practice, in which it was often perceived the difficulty of nursing professionals in carrying out physical examination, prescribing preventive actions and treating patients with risk factors or that has already been affected by the FI.

If such procedures are not performed correctly, the professional may put the customer at risk, with the possibility of damage and unexpected events.

Although the Basic Health Units (Unidades Básicas de Saúde-UBS), wound outpatient clinics and hospitals have a specialized skin lesion care service and follow protocols described on various procedures, these are not always being performed properly ${ }^{11,12}$. It was decided, then, to proceed with an integrative literature review in order to identify publications related to the theme of prevention and treatment of FI.

\section{Second stage: survey of content}

An integrative literature review was carried out. The following stages for the development of the research were delimited: identification of the theme and selection of the research question; establishment of criteria for the inclusion and exclusion of studies; definition of the information to be extracted from the selected studies and categorization of the studies; evaluation of studies included in the integrative review; interpretation of results, presentation of the review and synthesis of the knowledge $\mathrm{e}^{13 .}$

The theme was "educational booklet to prevent and treat FI".

The objective was to answer the following guiding question: does the developed educational booklet have satisfactory quality for use in the clinical practice of professional nurses? Will the educational booklet built in this study provide support for health professionals to develop preventive measures and therapeutic conduct for patients who present risk factors or have already contracted FI?

For the construction of the appropriate question for the resolution of the researched clinical question, the PICO strategy was used ${ }^{14}$, with "P" corresponding to the population (individual who presents risk factors or contracted FI), "I" to the intervention (preventing and treating FI), "C" to the comparison (not applicable, as this is not a comparative study) and " $\mathrm{O}$ " corresponding to the outcome (educational booklet). 
The integrative literature review took place through the databases Literatura Latino-Americana e do Caribe em Ciências da Saúde (LILACS), Medical Literature Analysis and Retrieval System Online (MEDLINE), Cumulative Index to Nursing and Allied Health Literature (CINAHL) and portal Scientific Electronic Library Online (SciElo). For the selection of articles, the following descriptors were used: the Descritores em Ciências da Saúde (DeCS) and the Medical Subject Headings, with controlled keywords: Friction; Wounds and injuries; and Nursing care, associated with each other using the Boolean operator AND.

For the selection of publications, the following inclusion criteria were adopted: only primary studies that have a direct connection with the theme, being available in full, being original articles and published between 2015 and 2020.

Exclusion criteria: theses, dissertations, monographs, technical reports and articles that, after reading the abstract, are not related to the proposed object of study, in addition to the publications that were repeated in the databases.

Titles and abstracts were read independently between two authors to ensure that the texts covered the guiding question of the review and met the inclusion criteria established. In case of doubt regarding the selection, it was decided to initially include the publication and decide on its selection only after reading its entire content.

To classify the level of evidence of the selected studies, were used the categories of Agency for Healthcare Research and Quality,covering six levels: level 1: evidence resulting from the meta-analysis of multiple controlled and randomized clinical trials; level 2: evidence obtained in individual studies with experimental design; level 3: evidence from quasi-experimental studies; level 4: evidence from descriptive (non-experimental) studies or qualitative approach; level 5: evidence from case or experience reports; level 6: evidence based on expert opinions.

As this is an integrative literature review and algorithm construction, this study did not require the approval of the Research Ethics Committee, however ethical aspects were considered, such as the citation of the authors of the selected articles.

From this survey, the booklet was prepared, which comprises a sequence described in four stages, with the topics: clinical evaluation, classification of the type of FI, preventive measures and therapeutic conduct.
The first stage describes the steps of the clinical evaluation and, at that moment, the educational booklet offers the items for the detailed comprehensive examination of the patient's skin conditions, associated risk factors that the patient presents to contract FI, adjacent skin conditions, edema, staining , aspect of ecchymosis, if the skin has a flap, if it appears pale, opaque or darkened, presence of bleeding, type of tissue, presence of exudate and measures the lesion.

The second stage classifies the type of FI. The Portuguese version of the "STAR Classification System - Friction Injury" was used. This instrument consists of three topics related to the care of the lesion and the surrounding skin, which are described below3,15,16.

On the type I FI there is no skin or flap loss. During the dressing, the professional can reposition (skin or flap) to cover the wound bed.

The type II FI (partial flap loss) shows partial loss of skin or flap; the skin cannot be repositioned, that is, to cover the lesion.

On the type III FI (total loss of the flap), the skin flap is completely absent, that is, the lesion is exposed, without protection.

On the third stage, preventive care was standardized, for example: use of hypoallergenic emollients or humectants to lubricate the skin, transfer technique, mobilization, decubitus change and transfer of the patient from one bed/stretcher to another in order to avoid or minimize the forces of rubbing, shearing, bruising and twisting, adhesive placement and removal technique and use of emollient soaps, with neutral $\mathrm{pH}$ and/or with Aloe vera, with the recommendation never to use alkaline, antibacterial or perfume soaps.

The fourth stage indicates the therapeutic approaches to treat FI. In this phase, local skin and lesion care and the ideal dressing are described, which aims to promote wound healing and reduce pain, and which is easily removed, acting as a protective barrier against bacterial invasion.

\section{Third stage: formulation/ assembly of the booklet}

The preliminary illustrations and content were developed and submitted to the editing and diagramming process, obeying the criteria related to content, structure/ organization, language, layout and design, cultural sensitivity and suitability for the elderly. This process was performed by an expert professional in the area. 
The images were selected from the internet and then converted into a drawing and worked in the Corel Draw ${ }^{\circledR}$ program, version 17 . The photos were authorized by the patients, originating the first version of the educational booklet submitted for validation, which was prepared in the period of March to May 2019. The second version was built between September and December 2019.

\section{Fourth stage: validation and implementation of the educational booklet to prevent and treat friction injuries}

The content validation of the educational booklet was carried out with nurses working in the treatment of wounds at Hospital das Clínicas Samuel Libânio, with stomatherapy nurses and specialist nurses in dermatology.

The inclusion criteria of the evaluators were: having a certificate of undergraduate nursing course with minimum experience of one year in treating patients with skin lesions. The exclusion criteria of the evaluators referred to the professionals who agreed to participate in the research, but did not answer and/or submitted the evaluation questionnaire within 15 days.

An invitation letter was sent to 48 professionals, however only 32 responded to the instrument's questions in 15 days.

The invitation letter consisted of: initial personal presentation and clarifications on the research topic, questionnaire to be evaluated by the judges, opinion of the Research Ethics Committee and the Informed Consent Form. The step by step of the steps for the effective participation of the evaluators was detailed, as well as the deadline of 15 days for each evaluation round, counting from the delivery day, to make and send the responses.

For the validation of the educational booklet, a questionnaire was developed by the author himself, which was divided into 2 parts: identification of the evaluator, with 4 questions and evaluation of the educational booklet, with 16 questions.

The judges analyzed the following items in the educational booklet: thematic content, graphic presentation, sequence, clarity and understanding of information, definition of FI, types of categories, risk factors, coverage used in different categories and preventive measures.

The Likert scale was used in the evaluation questions of the educational booklet, with the following answer options: "totally adequate", "adequate", "partially adequate", "inadequate" and "not applicable”.

The Delphi technique was adopted for the validation of the educational booklet. This method has the characteristic of obtaining opinions from evaluators with knowledge in the area through the use of questionnaires, in which the contents of the instruments are analyzed and judged by the judges in search of a consensus (50 to 100\%) among the evaluators. In this research, $100 \%$ consensus among the evaluators was chosen.

The data were compiled in a Microsoft ${ }^{\circledR}$ Office 365 program, version 1812, and, after coding and tabulation, analyzed using descriptive statistics. The experts' suggestions accepted by the researchers were added to the final version of the educational booklet.

The Content Validity Index was used to measure the proportion or percentage of judges who were in agreement on certain aspects of the instrument and its items. The value of the Content Validity Index for the validation of a questionnaire is calculated with the sum of the number of concepts, "adequate" and "totally adequate", divided by the total number of responses. The Content Validity Index value must be greater than or equal to 0.80 .

This study was approved by the Research Ethics Committee of the Faculdade de Ciências da Saúde Dr. José Antônio Garcia Coutinho, of the Universidade do Vale do Sapucaí (UNIVÁS), Pouso Alegre - MG, under Consubstantiated opinion number 1,426,916.

\section{RESULTS}

\section{Integrative literature review}

Initially, 2,977 articles were identified. Of these, 503 were excluded because they were duplicated in the databases. Thus, 1,008 articles were selected for reading the title and 43 for reading the abstract, which resulted in a sample of 23 articles for reading the full text. Of these, 5 were excluded because they did not answer the guiding question, which led to a total of 18 articles selected to build the educational booklet, as shown in Fig. 1.

Table 1 shows the articles selected during the integrative literature review to develop the educational booklet, which were classified according to the level of evidence. 


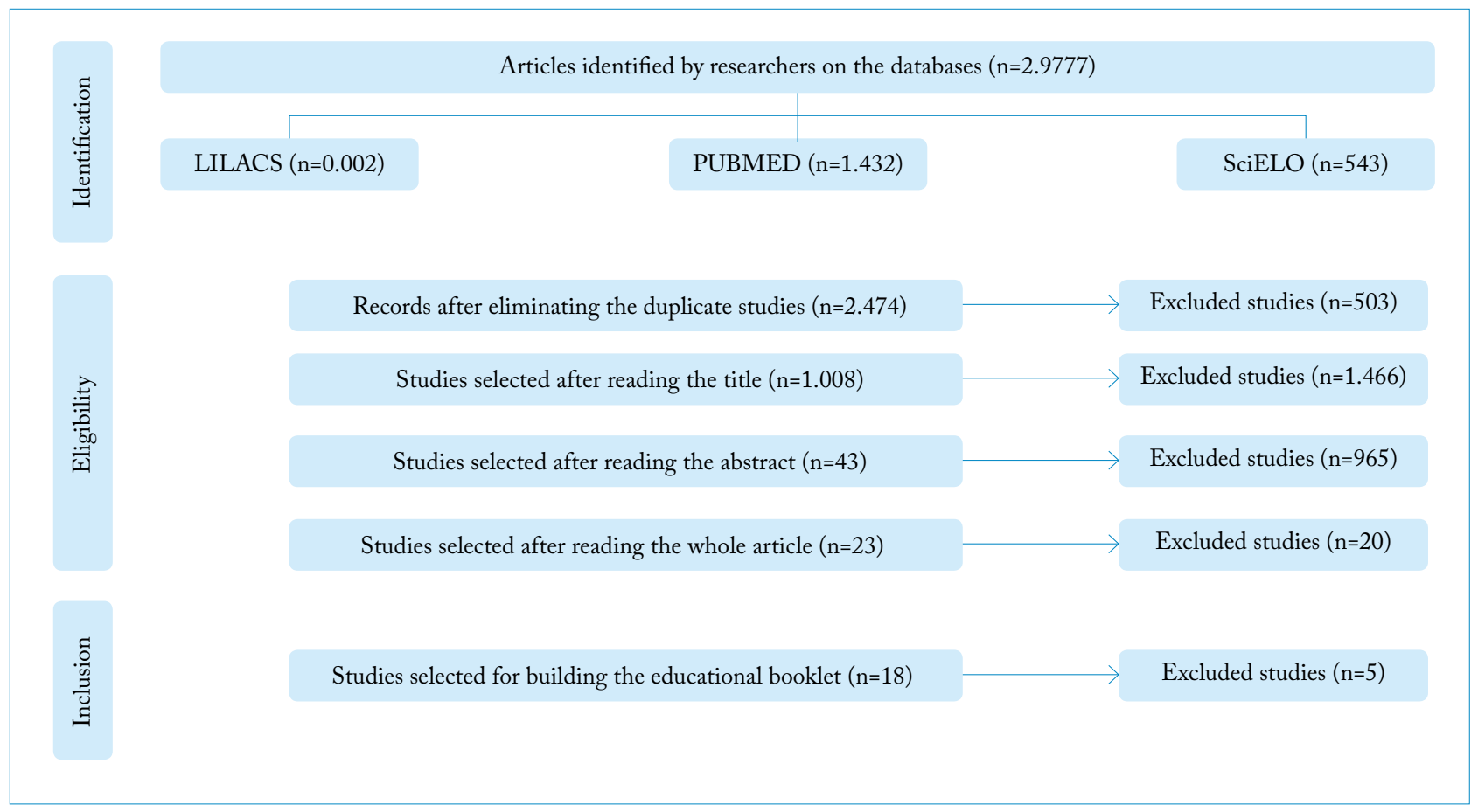

Figure 1. Flowchart of the process of identification, selection and inclusion of studies, elaborated based on the recommendation of the PRISMA. Pouso Alegre (MG), Brasil - 2020.

Table 1. Characteristics of the articles selected through the integrative literature review for the construction of the educational booklet. Pouso Alegre (MG), Brasil - 2020.

\begin{tabular}{|c|c|c|c|c|}
\hline & Author & Title & Journal/year/volume /issue & $\begin{array}{c}\text { Evidence } \\
\text { level }\end{array}$ \\
\hline 1 & $\begin{array}{l}\text { Lichterfeld-Kottner A, El } \\
\text { Genedy M, Lahmann N, } \\
\text { Blume-Peytavi U, Büscher } \\
\text { A, Kottner J.1 }\end{array}$ & $\begin{array}{l}\text { Maintaining skin integrity in the aged: } \\
\text { A systematic review. }\end{array}$ & $\begin{array}{l}\text { J. Int J Nurs Stud. 2020; 103: } 103509 . \\
\text { doi: } 10.1016 \text { / j.ijnurstu.2019.103509. }\end{array}$ & 04 \\
\hline 2 & $\begin{array}{c}\text { Rayner R, Carville K, Leslie } \\
\text { G, Dhaliwal SS. }\end{array}$ & $\begin{array}{l}\text { Models for predicting skin tears: A } \\
\text { comparison. }\end{array}$ & $\begin{array}{l}\text { Int Wound J. } 2020 \text { Jun;17(3):823-830. } \\
\text { doi: } 10.1111 / \text { iwj.13340. }\end{array}$ & 04 \\
\hline 3 & $\begin{array}{l}\text { da Silva CVB, Campanili } \\
\text { TCGF, Freitas NO, LeBlanc } \\
\text { K, Baranoski S, Santos } \\
\text { VLCG. }\end{array}$ & $\begin{array}{l}\text { Istap classification for skin tears: } \\
\text { Validation for Brazilian Portuguese. }\end{array}$ & $\begin{array}{l}\text { Int Wound J. } 2020 \text { Abr;17(2):310-316. } \\
\text { doi: 10.1111/iwj.13271. }\end{array}$ & 03 \\
\hline 4 & $\begin{array}{l}\text { Scheele CM, Göhner W, } \\
\text { Schumann } \mathrm{H}^{4}\end{array}$ & $\begin{array}{l}\text { Cross-sectional study on skin tears in } \\
\text { fragile, aging skin: nursing deficits in a } \\
\text { common problem in Germany. }\end{array}$ & $\begin{array}{l}\text { The Pflege. 2020; } 33 \text { (3): 123-132. } \\
\text { doi: } 10.1024 \text { / 1012-5302 / a000742. }\end{array}$ & 03 \\
\hline 5 & $\begin{array}{l}\text { Langemo DK, Williams A, } \\
\text { Edwards K. }{ }^{5}\end{array}$ & $\begin{array}{l}\text { Skin tears: prevention and } \\
\text { management. }\end{array}$ & $\begin{array}{c}\text { Nursing. } 2019 \text { Abr; } 49 \text { (4): } \\
\text { 66-69. doi: } 10.1097 / 01 . \\
\text { NURSE.0000554309.45660.ca }\end{array}$ & 04 \\
\hline 6 & $\begin{array}{c}\text { Rayner R, Carville K, Leslie } \\
\text { G, Dhaliwal SS. }{ }^{6}\end{array}$ & $\begin{array}{l}\text { A risk model for prediction of skin } \\
\text { tears in aged care residents: a } \\
\text { prospective cohort study. }\end{array}$ & $\begin{array}{c}\text { Int Wound J. } 2019 \text { Feb; } 16 \text { (1): 52-63. } \\
\text { doi: } 10.1111 \text { / iwj.12985. }\end{array}$ & 03 \\
\hline 7 & Brown $A^{7}$ & $\begin{array}{l}\text { Skin tears: Prevention and } \\
\text { management in the elderly }\end{array}$ & $\begin{array}{l}\text { J Community Nurs 2019: } \\
\text { 33(1):p22-28. }\end{array}$ & 04 \\
\hline 8 & $\begin{array}{c}\text { Campbel K, LeBlanc K, } \\
\text { Woo K }{ }^{8}\end{array}$ & $\begin{array}{l}\text { Best practice recommendations for } \\
\text { prevention and management of skin } \\
\text { tears in aged skin: an overview. }\end{array}$ & $\begin{array}{l}\text { Wounds International. } \\
\text { 2018; } 9 \text { (3):66-70. 10.1097/ } \\
\text { WON.0000000000000481 }\end{array}$ & 04 \\
\hline 9 & Mclnulty $L^{9}$ & $\begin{array}{l}\text { Prevention and management of skin } \\
\text { tears in older people. }\end{array}$ & $\begin{array}{l}\text { Emerg Nurse. } 2017 \text { Jun 15;25(3):32- } \\
\text { 39. doi: } 10.7748 / \text { en.2017.e1687. }\end{array}$ & 04 \\
\hline
\end{tabular}


Tabela 1. Continuation...

\begin{tabular}{|c|c|c|c|c|}
\hline & Author & Title & Journal/year/volume /issue & $\begin{array}{l}\text { Evidence } \\
\text { level }\end{array}$ \\
\hline 10 & $\begin{array}{l}\text { Brandão CMAG, Gambin } \\
\text { CC; Majado CA, Kunitake } \\
\text { N, AlexandreNMC, Dantas } \\
\text { SRPE }{ }^{15}\end{array}$ & $\begin{array}{l}\text { Adaptação do instrumento } \\
\text { "Perineal Assessment Tool" para a } \\
\text { cultura brasileira. }\end{array}$ & $\begin{array}{c}\text { ESTIMA, Braz. J. Enterostomal } \\
\text { Ther.16:e0618. } \\
\text { doi:10.30886/estima.v16.397_PT. }\end{array}$ & 03 \\
\hline 11 & $\begin{array}{l}\text { Torres FS, Blanes L, Freire } \\
\text { Galvão T, Masako Ferreira L }{ }^{16}\end{array}$ & $\begin{array}{l}\text { Development of a manual for the } \\
\text { prevention and treatment of skin tears. }\end{array}$ & $\begin{array}{l}\text { Wounds. } 2018.31(1): 26- \\
\text { 32. doi: } 10.1097 / 01 \\
\text { ASW.0000405316.99011.95. }\end{array}$ & 04 \\
\hline 12 & $\begin{array}{c}\text { Tristão FR, Girondi JBR, } \\
\text { Hammerschmidt KSA, } \\
\text { Soares CF, Martins T, Lima } \\
\text { DKS. }{ }^{17}\end{array}$ & $\begin{array}{l}\text { Risco para lesão por fricção em } \\
\text { idosos longevos na atenção primária } \\
\text { à saúde. }\end{array}$ & $\begin{array}{c}\text { ESTIMA, Braz. J. Enterostomal Ther., } \\
\text { 16: e3218. https://doi.org/10.30886/ } \\
\text { estima.v16.614_PT. }\end{array}$ & 04 \\
\hline 13 & $\begin{array}{l}\text { Serra R,Lelapi N, Barbetta } \\
\text { A, De Francisci S }{ }^{18}\end{array}$ & $\begin{array}{l}\text { Skin tears and risk factors } \\
\text { assessment: a systematic review on } \\
\text { evidence-based medicine. }\end{array}$ & $\begin{array}{l}\text { Int Wound J. 2018;15(1):38-42. } \\
\text { https://doi.org/10.12968/ } \\
\text { bjcn.2019.24.Sup9.S12 }\end{array}$ & 02 \\
\hline 14 & $\begin{array}{c}\text { Koyano Y, Nakagami G, lizaka } \\
\text { S, Sugama J, Sanada } H^{19}\end{array}$ & $\begin{array}{c}\text { Skin property can predict the } \\
\text { development of skin tears among } \\
\text { elderly patients: a prospective } \\
\text { cohort study. }\end{array}$ & $\begin{array}{l}\text { Int Wound J. } 2017 \text { Aug; } 14 \text { (4): } 691 \text { - } \\
\text { 697. doi: } 10.1111 \text { / iwj.12675. }\end{array}$ & 03 \\
\hline 15 & Candeloro G. ${ }^{20}$ & $\begin{array}{l}\text { Skin tears. A quantitative study on } \\
\text { the phenomenon and proposal } \\
\text { for a prevention and management } \\
\text { procedure. }\end{array}$ & $\begin{array}{l}\text { Journal of Wound Care 2017; } \\
\qquad 1(2): 61-66\end{array}$ & 04 \\
\hline 16 & Benbow M. ${ }^{21}$ & $\begin{array}{l}\text { Assessment, prevention and } \\
\text { management of skin tears. }\end{array}$ & $\begin{array}{c}\text { Nursing of the elderly. } 2017 \text { Apr } \\
\text { 28; } 29 \text { (4): 31-39. doi: } 10.7748 \text { / } \\
\text { nop.2017.e904. }\end{array}$ & 04 \\
\hline 17 & LeBlanc K, Baranoski S. ${ }^{22}$ & Skin Tears: Finally Recognized. & $\begin{array}{l}\text { Adv Skin Wound Care. } \\
\text { 2017;30(2):62-63. doi: 10.1097/01. } \\
\text { ASW.0000511435.99585.0d }\end{array}$ & 04 \\
\hline
\end{tabular}

The final version of the educational booklet called "Lesão por fricção: conceitos, medidas preventivas e conduta terapêutica” ("Friction injury: concepts, preventive measures and therapeutic conduct"), contains 45 pages, including the cover, back cover with the catalog card and the International Standard Book Number 978-8567647-64-7, list of illustrations, list of tables, summary, preface, presentation and 3 chapters (introduction, anatomy and physiology of friction injury). The "friction injury" chapter was subdivided into: definition, risk factors, classification, preventive measures and therapeutic approaches for FI. There are two algorithms, one with preventive measures and the other with therapeutic procedures and bibliographic references, in standard formatting format, $21 \mathrm{~cm}$ high by 15 $\mathrm{cm}$ wide, according to the image in Fig. 2.

Each page has up to five illustrations, totaling 22 illustrations, which can be seen in Fig. 2. The booklet is available for free only at the link: http://www.univas.edu.br/ menu/biblioteca/publicacoes.asp

\section{Final version of the educational booklet}

In Table 2, we observed that the judges used the Delphi technique during the evaluation of the booklet content. In the first round, the judges evaluated the contents of the booklet with concepts such as: "partially adequate" to "totally adequate".

Table 3 shows that in the first evaluation of the educational booklet, there was no consensus among the evaluators on the questions: description of the definition of category $1 \mathrm{a}$ and $1 \mathrm{~b}$, category $2 \mathrm{a}$ and $2 \mathrm{~b}$ and category 3 of the FI, and the Content Validity Index varied between 0.77 and 0.81 . After making adjustments to the questions (description of the definition of FI type I, description of the definition of FI type II, description of the definition of FI type III), the judges reassessed the booklet, with a consensus between them. The Content Validity Index was 1.0. This result indicates that the content of the educational booklet is excellent. 


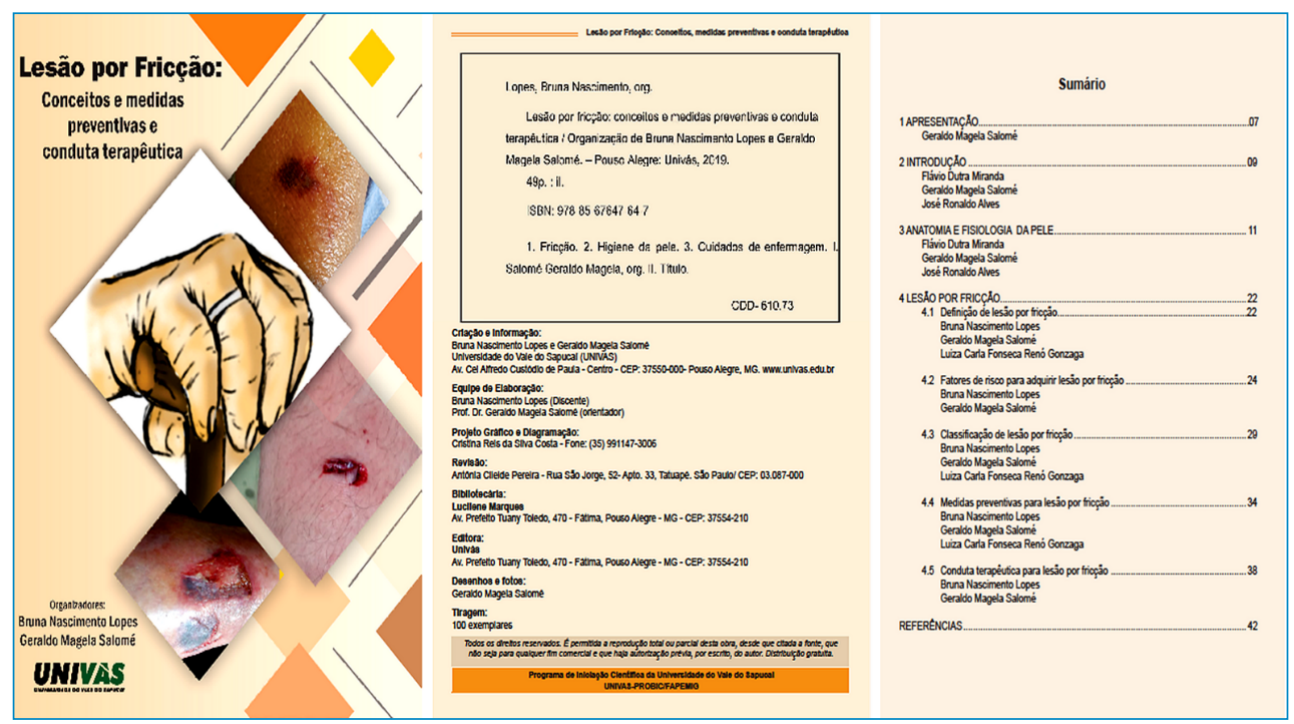

Figure 2. Cover, catalog and summary of the booklet Friction Injury: concepts, preventive measures and therapeutic conduct. Pouso Alegre (MG), Brasil - 2020.

Table 2. Evaluation of the content of the educational booklet by the judges, according to the Delphi Technique. Pouso Alegre (MG), Brasil - 2020.

\begin{tabular}{|c|c|c|c|c|c|}
\hline \multirow{3}{*}{ Questions } & Inadequate & $\begin{array}{l}\text { Partially } \\
\text { adequate }\end{array}$ & Adequate & $\begin{array}{c}\text { Totally } \\
\text { Adequate }\end{array}$ & Total \\
\hline & \multicolumn{5}{|c|}{ First evaluation } \\
\hline & $\mathrm{N}(\%)$ & $\mathrm{N}(\%)$ & $\mathrm{N}(\%)$ & $N(\%)$ & $\mathrm{n}(\%)$ \\
\hline Graphical presentation & $00(0.0)$ & $00(0.0)$ & $07(21.875)$ & $25(78.125)$ & $32(100)$ \\
\hline Ease of reading & $00(0.0)$ & $00(0.0)$ & $05(15.625)$ & $27(84.375)$ & $32(100)$ \\
\hline Thematic content of the booklet & $00(0.0)$ & $00(0.0)$ & $08(25.00)$ & $24(75.00)$ & $32(100)$ \\
\hline Vocabulary & $00(0.0)$ & $00(0.0)$ & $01(3.125)$ & $31(96.875)$ & $32(100)$ \\
\hline Clarity and understanding of information & $00(0.0)$ & $00(0.0)$ & $01(3.125)$ & $31(96.875)$ & $32(100)$ \\
\hline Definition of friction injury & $00(0.0)$ & $00(0.0)$ & $03(9.375)$ & $29(90.625)$ & $32(100)$ \\
\hline Description of risk factors for friction injury & $00(0)$ & $01(3.125)$ & $03(9.375)$ & $28(87.500)$ & $32(100)$ \\
\hline $\begin{array}{l}\text { Description of the definition of category } 1 a \\
\text { and } 1 b \text { of the friction injury }\end{array}$ & $06(18.75)$ & $06(18.75)$ & $06(18.750)$ & $14(43.75)$ & $32(100)$ \\
\hline Description of the friction injury Category $2 \mathrm{a}$ and $2 \mathrm{~b}$. & $00(0.0)$ & $01(03.125)$ & $06(18.750)$ & $25(78.125)$ & $32(100)$ \\
\hline Description of the friction injury Category 3. & $07(21.875)$ & $05(15.625)$ & $06(18.750)$ & $14(43.750)$ & $32(100)$ \\
\hline Preventive measures for friction injury & $00(0.0)$ & $01(03.125)$ & $05(15.625)$ & $26(81.250)$ & $32(100)$ \\
\hline Therapeutic management for friction injury & $07(21.875)$ & $04(12.500)$ & $03(0.375)$ & $18(56.250)$ & $32(100)$ \\
\hline \multirow{2}{*}{ Questions } & \multicolumn{5}{|c|}{ Second evaluation } \\
\hline & $N(\%)$ & $N(\%)$ & $N(\%)$ & $N(\%)$ & n (\%) \\
\hline Graphical presentation & $00(0.0)$ & $00(0.0)$ & $07(21.875)$ & $25(78.125)$ & $32(100)$ \\
\hline Ease of reading & $00(0.0)$ & $00(0.0)$ & $01(3.125)$ & $31(96.875)$ & $32(100)$ \\
\hline Thematic content of the booklet & $00(0.0)$ & $00(0.0)$ & $03(9.375)$ & $29(90.625)$ & $32(100)$ \\
\hline Vocabulary & $00(0.0)$ & $00(0)$ & $03(15.625)$ & $17(84.375)$ & $32(100)$ \\
\hline Clarity and understanding of information & $00(0.0)$ & $00(0.0)$ & $01(3.125)$ & $31(96.875)$ & $32(100)$ \\
\hline Definition of friction injury & $00(0.0)$ & $00(0.0)$ & $03(9.375)$ & $29(90.625)$ & $32(100)$ \\
\hline Description of risk factors for friction injury & $00(0.0)$ & $00(0.0)$ & $03(9.375)$ & $29(90.625)$ & $32(100)$ \\
\hline Description of the type I friction injury definition & $00(0.0)$ & $00(0.0)$ & $07(21.875)$ & $25(78.125)$ & $32(100)$ \\
\hline Description of the type II friction injury definition & $00(0.0)$ & $00(0.0)$ & $01(3.125)$ & $31(96.875)$ & $32(100)$ \\
\hline Description of the type III friction injury definition & $00(0.0)$ & $00(0)$ & $03(15.625)$ & $17(84.375)$ & $32(100)$ \\
\hline Preventive measures for friction injury & $00(0.0)$ & $00(0.0)$ & $07(21.875)$ & $25(78.125)$ & $32(100)$ \\
\hline Therapeutic management for friction injury & $00(0.0)$ & $00(0.0)$ & $07(21.875)$ & $25(78.125)$ & $32(100)$ \\
\hline
\end{tabular}


Table 3. Content Validity Index obtained in the first and second cycle of evaluation of the items in the educational booklet. Pouso Alegre (MG), Brasil - 2020.

\begin{tabular}{|c|c|}
\hline \multirow[t]{2}{*}{ Questions } & $\begin{array}{l}\text { Content Validity } \\
\text { Index }\end{array}$ \\
\hline & First evaluation \\
\hline Graphical presentation & 0.79 \\
\hline Ease of reading & 0.81 \\
\hline Thematic content of the booklet & 0.79 \\
\hline Vocabulary & 0.81 \\
\hline $\begin{array}{l}\text { Clarity and understanding } \\
\text { of information }\end{array}$ & 0.81 \\
\hline Definition of friction injury & 0.80 \\
\hline $\begin{array}{l}\text { Description of risk factors } \\
\text { for friction injury }\end{array}$ & 0.80 \\
\hline $\begin{array}{l}\text { Description of the definition of category } \\
1 \mathrm{a} \text { and } 1 \mathrm{~b} \text { of the friction injury }\end{array}$ & 0.76 \\
\hline $\begin{array}{l}\text { Description of category } 2 \mathrm{a} \text { and } 2 \mathrm{~b} \\
\text { of the friction injury }\end{array}$ & 0.80 \\
\hline $\begin{array}{l}\text { Description of category } 3 \\
\text { of the friction injury }\end{array}$ & 0.77 \\
\hline $\begin{array}{l}\text { Preventive measures } \\
\text { for friction injury }\end{array}$ & 0.80 \\
\hline $\begin{array}{c}\text { Therapeutic management for } \\
\text { friction injury }\end{array}$ & 0.78 \\
\hline General CVI & 0.81 \\
\hline \multirow[t]{2}{*}{ Questions } & $\begin{array}{l}\text { Content Validity } \\
\text { Index }\end{array}$ \\
\hline & Second evaluation \\
\hline Graphical presentation & ${ }^{*} 1.0$ \\
\hline Ease of reading & $* 1.0$ \\
\hline Thematic content of the booklet & ${ }^{*} 1.0$ \\
\hline Vocabulary & $* 1.0$ \\
\hline $\begin{array}{l}\text { Clarity and understanding } \\
\text { of information }\end{array}$ & ${ }^{*} 1.0$ \\
\hline Definition of friction injury & ${ }^{*} 1.0$ \\
\hline $\begin{array}{l}\text { Description of risk factors } \\
\text { for friction injury }\end{array}$ & ${ }^{*} 1.0$ \\
\hline $\begin{array}{l}\text { Description of the type I } \\
\text { friction injury definition }\end{array}$ & ${ }^{*} 1.0$ \\
\hline $\begin{array}{l}\text { Description of the type } \| \\
\text { friction injury definition }\end{array}$ & ${ }^{*} 1.0$ \\
\hline $\begin{array}{l}\text { Description of the type II } \\
\text { friction injury definition }\end{array}$ & ${ }^{*} 1.0$ \\
\hline $\begin{array}{l}\text { Preventive measures } \\
\text { for friction injury }\end{array}$ & ${ }^{*} 1.0$ \\
\hline $\begin{array}{l}\text { Therapeutic management } \\
\text { for friction injury }\end{array}$ & $* 1.0$ \\
\hline Ease of reading & ${ }^{*} 1.0$ \\
\hline General CVI & $* 1.0$ \\
\hline
\end{tabular}

*Excellent Content Validity Index; CVI = Content Validity Index

\section{DISCUSSION}

The booklet validated in this research was developed after a literature review. This instrument can assist health professionals, who care for individuals who have risk factors or have acquired FI, in the clinical evaluation, offering preventive measures and therapeutic approaches to promote the healing of FI.

An educational booklet is an effective method to assist in the teaching-learning process in health and in the clinical practice of the professional, in order to increase their autonomy, enabling better clinical conduct ${ }^{11,12}$.

Several studies recommend that the booklets, manuals and protocols should be constructed after the literature review, so the professional will be developing an educational technology based on scientific subsidies, facilitating the implementation in clinical practice, the provision of systematic, individualized and personalized assistance, with lower risk to the patient, without damage and adverse events ${ }^{11,12,23}$.

The educational material in printed format is easy to handle and can be taken home, strengthening the guidelines and solving doubts whenever necessary. The written material has functions, such as reinforcing information and oral discussions and assisting in cases of later doubts and in clinical decisions ${ }^{24,25}$.

The material developed in this study brings advantages to the health professional, as it was constructed with always clear and objective language and validated by experienced professionals and specialists in the area. It also offers items that help professionals to assess patients' skin, identify risk factors, in addition to providing protocol in the form of algorithms, being one for prevention and the another for treatment, and in a descriptive way, it includes the new classification of the type of FI, preventive measures and therapeutic approaches for FI.

Educational technologies, whatever the clinical situation, improve the knowledge and satisfaction of the target audience. The content must have a clear, simple and easy to understand vocabulary ${ }^{26}$.

An educational technology, in order to be effective and have a greater professional reach, must be developed with a simple language, which conveys a clear and objective message, facilitating the understanding and execution of the procedure pi1,12,27. $^{1}$.

In this research, the judges used the Delphi Technique to evaluate the content of the educational booklet. In the first 
evaluation, there was no consensus among the evaluators. After the corrections made based on the comments of the judges and with scientific basis, the booklet was sent back to the judges, and there was then a consensus among them. In the first evaluation, the Content Validity Index of all questions was 0.81 . After making the corrections suggested by the evaluators, the booklet was sent for another evaluation and the Content Validity Index was 1.0, which is a significant result, since it was above the minimum agreement value of $80 \%$.

This result shows that the content of the booklet developed in this study has the potential to be transmitted to the target audience in a clear, simple, objective manner and with an appropriate vocabulary for the population, which favors the understanding of the information regarding its technical and didactic-pedagogical aspects, without (or reducing) the possibility of erroneous interpretations.

Several studies that validated the educational technology content using the Delphi technique concluded that the evaluators' suggestions should be considered and incorporated. This procedure contributes to a better understanding, effectiveness and implantation of the material in the institution, allowing the target audience to understand the content of the material and to be encouraged to use it ${ }^{11,12,14,24,27}$.

When an educational booklet is validated by professionals with experience in the area and the Content Validity Index is above 1.0, it means that the evaluators considered the information contained in the booklet to be relevant, which is extremely important for this technology to be used as a tool in clinical practice and health education.
Scientific validation by the target audience gives credibility to the material ${ }^{11,12}$.

In the first version of the booklet developed in this study, several changes requested by the judges were implemented. After the adjustments, the booklet was reassessed, with consensus among the evaluators. This critical analysis was fundamental for the improvement of the new version of the educational booklet

The booklet developed is intended to guide health professionals in clinical practice, to provide timely assistance to individuals, in an effective, systematized, individualized, personalized manner, with the minimum possible risk, without damage and adverse events, providing assistance with safety.

\section{CONCLUSION}

The content of the educational booklet was constructed and validated. In the first evaluation, it presented 0.81 of Content Validity Index, meaning that the booklet has good content, and several suggestions were made. After making the corrections indicated by the evaluators, the booklet was reassessed and the Content Validity Index was 1.0, characterizing that the booklet has excellent content.

The booklet built in this study provides conditions for the professional to perform clinical evaluation, detect risk factors and prescribe preventive measures and therapeutic approaches. It also facilitates the recording of the characteristics of the FI, ensuring the monitoring of the evolution of the lesion, minimizing the risks, damages and adverse events.

\section{REFERÊNCIAS}

1. Lichterfeld-Kottner A, El Genedy M, Lahmann N, BlumePeytavi U, Büscher A, Kottner J. Maintaining skin integrity in the aged: a systematic review. Int J Nurs Stud 2020;103:103509. https://doi.org/10.1016/j.ijnurstu.2019.103509

2. Rayner R, Carville K, Leslie G, Dhaliwal SS. Models for predicting skin tears: A comparison. Int Wound J. 2020 Jun;17(3):823-830. https://doi.org/10.1111/iwj.13340

3. Silva CVB, Camanili TCGF, Freitas NO, LeBlanc K, Baranoski S, Santos VLCG. ISTAP classification for skin tears: validation for brazilian portuguese. Int Wound J 2020;17(2):310-6. https://doi.org/10.1111/iwj.13271

4. Scheele CM, Göhner W, Schumann H. Cross-sectional study on skin tears in fragile, aging skin: nursing deficits in a common problem in Germany. Pflege 2020;33(3):123-32. https://doi.org/10.1024/1012-5302/a000742

5. Langemo DK, Williams A, Edwards K. Skin tears: prevention and management. Nursing 2019;49(4):66-9. https://doi. org/10.1097/01.NURSE.0000554309.45660.ca

6. Rayner R, Carville K, Leslie G, Dhaliwal SS. A risk model for prediction of skin tears in aged care residents: a prospective cohort study. Int Wound J 2019;16(1):52-63. https://doi. org/10.1111/iwj.12985

7. Brown A. Skin tears: Prevention and management in the elderly. J Community Nurs 2019:33(1):22-8. Available at: https://www.researchgate.net/publication/331839054_ Skin_tears_Prevention_and_management_in_the_elderly 
8. LeBlanc K, Campbel KE, Wood E, Beeckman D. Best practice recommendations for prevention and management of skin tears in aged skin: an overview. J Wound Ostomy Continence Nurs 2018;45(6):540-2. https://doi.org/10.1097/ WON.0000000000000481

9. Mclnulty L. Prevention and management of skin tears in older people. Emerg Nurs 2017;25(3):32-9. https://doi. org/10.7748/en.2017.e1687

10. Catania QN, Morgan M, Martin R. Activity-Based Restorative Therapy and Skin Tears in Patients with Spinal Cord Injury. Adv Skin Wound Care 2018;31(8):371-3. https://doi. org/10.1097/01.ASW.0000534700.57785.84

11. Salomé GM, Cunha AL, Pereira AP, Miranda FD, Alves JR. Educational handbook for healthcare professionals: preventing complications and treating peristomal skin. J Coloproctol 2019;39(4):332-8. https://doi.org/10.1016/j. jcol.2019.07.005

12. Mendes B, Salomé GM, Pinheiro FAM, Júnior MRM, Cunha DR, Ferreira LM. Preventing and treating trench foot: validation of an educational manual for military personnel. J Wound Care 2018;27(Sup10):S33-8. https://doi.org/10.12968/ jowc.2018.27.Sup10.S33

13. Mendes KDS, Silveira RCCP, Galvão CM. Revisão integrativa: método de pesquisa para a incorporação de evidências na saúde e na enfermagem. Texto Contexto Enferm 2008;17(4):758-64. http://doi.org/10.1590/S010407072008000400018

14. Santos CMC, Pimenta CAM, Nobre MRC. The Pico strategy for the research question construction and evidence search. Rev Latino-Am Enfermagem 2007;15(3):508-11. https://doi. org/10.1590/s0104-11692007000300023

15. Brandão ACMAG, Gambin CC; Majado CA, Kunitake N, Alexandre NMC, Dantas SRPE. Adaptação do instrumento "Perineal Assessment Tool" para a cultura brasileira. ESTIMA, Braz J Enterostomal Ther 2018;16:e0618. https:// doi.org/10.30886/estima.v16.397_PT

16. Torres FS, Blanes L, Galvão TF, Ferreira LM. Development of a manual for the prevention and treatment of skin tears. Wounds 2018; [cited on 01 dec 2020]; 31(1):26-32. Available at: https://www.biosanas.com.br/uploads/outros/artigos_ cientificos/51/adc7302e06f88ce154d9b5ee99f472aa.pdf

17. Tristão FR, Girondi JBR, Hammerschmidt KSA, Soares CF, Martins T, Lima DKS. Risco para lesão por fricção em idosos longevos na atenção primária à saúde. ESTIMA,
Braz J Enterostomal Ther 2018;16:e3218. https://doi. org/10.30886/estima.v16.614_PT

18. Serra R, lelapi N, Barbetta A, Franciscis S. Skin tears and risk factors assessment: a systematic review on evidencebased medicine. Int Wound J. 2018;15(1):38-42. https://doi. org/10.1111/iwj.12815

19. Koyano Y, Nakagami G, lizaka S, Sugama J, Sanada H. Skin property can predict the development of skin tears among elderly patients: a prospective cohort study. Int Wound J 2017;14(4):691-7. https://doi.org/10.1111/iwj.12675

20. Candeloro G. Skin tears. A quantitative study on the phenomenon and proposal for a prevention and management procedure. Ital J Wound Care 2017;1(2):61-6. https://doi.org/10.4081/ijwc.2017.13

21. Benbow M. Assessment, prevention and management of skin tears. Nursing Older People 2017;29(4):31-9. https:// doi.org/10.7748/nop.2017.e904

22. LeBlanc K, Baranoski S. Skin Tears: Finally Recognized. Adv Skin Wound Care. 2017;30(2):62-63. https://doi. org/10.1097/01.ASW.0000511435.99585.0d

23. Normansell R, Kew KM, Mathioudakis AG. Interventions to improve inhaler technique for people with asthma. Cochrane Database Syst Rev 2017; 3(3):CD012286. https:// doi.org/10.1002/14651858.CD012286.pub2

24. Salomé GM, Alves NF. App "SICKSEG" in mobile platform for the prevention of skin injuries. J Nurs UFPE on line 2020;14:e244152. https://doi.org/10.5205/19818963.2020 .244152

25. Santos I, Brandão ES, Clós AC. Dermatology nursing: sensitive listening skills and technology for acting in skin care. Rev Enferm UERJ 2009; [citado 2019 ago 10]; 17(1):124-9. Available at: http://files.bvs.br/upload/S/0104-3552/2009/ v17n1/a022.pdf

26. Carvalho MRF, Salomé GM, Ferreira LM. Construction and validation of algorithm for treatment of pressure injury. J Nurs UFPE on line 2017;11(Suppl. 10):4171-83. https://doi. org/10.5205/reuol.10712-95194-3-SM.1110sup201722

27. Salomé GM, Rocha CA, Miranda FD, Alves JR, Dutra RAA, Tenório AG. Algoritmos para prevenção e tratamento de dermatite associada à incontinência. ESTIMA, Braz J Enterostomal Ther 2020:e1320. https://doi.org/10.30886/ estima.v18.837_IN 